\title{
New approaches to the action of silicon to enable the cultivation of Panicum maximum in soil with water restriction
}

Juan Ricardo Rocha ( $\sim$ juan.rocha.ricardo@gmail.com )

São Paulo State University (UNESP)

Renato Mello Prado

São Paulo State University (UNESP)

Marisa Cássia Piccolo

University of São Paulo (USP)

\section{Research Article}

Keywords: Pasture (Poaceas), physiological stress, physiological function, water, Agriculture

Posted Date: July 27th, 2021

DOl: https://doi.org/10.21203/rs.3.rs-733460/v1

License: (c) (i) This work is licensed under a Creative Commons Attribution 4.0 International License.

Read Full License 


\section{Abstract}

Climate change increases the occurrence of droughts, decreasing the production of tropical forages through the induction of physiological stress. $\mathrm{Si}$ is expected to broaden the limit from physiological stress of forages grown under water restriction, which may come from an improvement in the stoichiometric homeostasis of Si with $\mathrm{N}$ and $\mathrm{C}$, favoring physiological aspects. This study assessed whether Si supply via fertigation improves physiological aspects and the water content in the plant by means of an antioxidant defense system and changes in the C:N:Si stoichiometry during the regrowth of two cultivars of Panicum maximum grown under two soil water regimes (70 and $40 \%$ of the soil's water retention capacity). The forages studied are sensitive to water deficit without silicon supply. The application of $\mathrm{Si}$ via fertigation attenuated the water deficit, favoring plant growth by stabilizing the stoichiometric homeostasis $\mathrm{C}: \mathrm{N}$ and $\mathrm{C}: \mathrm{Si}$, which are responsible for increasing the plant capacity of converting accumulated $\mathrm{C}$ in dry mass, favoring the water content of the plant tissue and the photosynthetic efficiency. This study highlights the importance of the physiological function of $\mathrm{Si}$, and effects on the stoichiometry of $\mathrm{C}$ and $\mathrm{N}$, which are neglected in most research on forages grown under water restriction.

\section{Introduction}

Pasture (Poaceas) is used as the main source of food for cattle raised in tropical regions of the world because it is the most economical and practical way of feeding the herd, and it serves as a basis for world livestock production systems ${ }^{1,2}$. The Panicum maximum species stands out owing to its high biomass production capacity, quality of forage, ease of establishment and acceptability by animals ${ }^{3}$. Despite its adaptability to stationary changes, it is sensitive to periods of drought ${ }^{4}$.

Abiotic stresses such as drought ${ }^{5}$ and high temperature ${ }^{6}$ threaten the persistence and pasture capacity for biomass production ${ }^{7}$, mainly in regrowth. Therefore, water is the main limiting factor in agricultural production ${ }^{8}$, and this problem can be aggravated by the impacts of climate change, as extreme events can induce irregular rainfall and cause drought ${ }^{9,10}$.

The effects of drought on plants are known to induce water loss in the tissues and physiological disturbances in photosynthesis, loss of membrane integrity and generation of reactive oxygen species (ROS) ${ }^{11,12}$. It should be noted that stoichiometric homeostasis is useful to explain and predict the responses of differential plants to stresses such as drought ${ }^{13}$.

In a drought situation, a plant's defense system is activated to minimize damage, especially in species that absorb silicon, which is a relevant strategy to mitigate such stress. Most studies to date on Si and water deficit in different species have discussed the effect of the latter on decreasing the transpiratory rate, which increases water use efficiency ${ }^{14,15}$.

New pasture research has indicated that, through Si uptake, plants can improve their physiological aspects and water content, but they use this mechanism primarily to modify elementary stoichiometry 
and to use $\mathrm{C}$ to minimize the damage caused by water deficit in plants of Brachiaria spp. cultivars Ipyporã and Mavuno ${ }^{16}$ and in sugarcane plants ${ }^{17}$. While most studies on stoichiometric homeostasis have focused especially on $\mathrm{N}$ and $\mathrm{P}$, studies with $\mathrm{Si}$ are incipient ${ }^{18,19}$.

It has been reported that $\mathrm{Si}$ absorption varies depending on the genetic factor ${ }^{20}$; however, what still needs to be checked is whether or not this benefit of the element occurs in other pasture species, such as Panicum maximum, which is widely cultivated worldwide, especially because it supports many regrowths. There are indications of $\mathrm{Si}$ involvement in reducing oxidative stress by increasing the synthesis of antioxidant compounds ${ }^{21,22}$, but these benefits may be due to the improvement of elementary stoichiometric (C:N) homeostasis. Therefore, further research is needed to prove this assumption.

In this context, the following hypothesis should be tested: whether Si can attenuate water deficit because plants can tolerate a higher level of physiological stress after stoichiometric homeostasis has been improved, which changes the C:N and C:Si ratios and, consequently, affects the capacity of plants to convert cumulative $\mathrm{C}$ into dry weight, as favored by some physiological processes and the growth of two cultivars of Panicum maximum.

These results aid the systematic assessment of the impacts of Si accumulation on the increase of the limit of physiological stress of plants owing to its effect on the stoichiometry of $\mathrm{C}$ and $\mathrm{N}$ in pastures. Also, they provide references for the management of pastures under water restriction.

To test the hypothesis, this study was carried out to assess whether Si supply via fertigation improves physiological aspects and water content in the plant by involving the antioxidant defense system and modifies the $\mathrm{C}: \mathrm{N}: \mathrm{Si}$ stoichiometry and the regrowth performance of two $P$. maximum cultivars grown under two soil water regimes ( 70 and $40 \%$ of soil water retention capacity).

\section{Material And Methods}

Two trials were carried out at São Paulo State University (UNESP), in Jaboticabal, Brazil in the year 2020, concerning the second growth cycle or the regrowth of Panicum maximum cultivars Massai (experiment 1) and BRS Zuri (experiment 2).

Seeds of $P$. Maximum, were obtained from the Brazilian Agricultural Research Corporation of the Ministry of Agriculture, Livestock and Food Supply, Brazil (registered and protected by the Ministry of Agriculture, Livestock and Supply - MAPA). This research was not conducted with endangered species and was conducted in accordance with the is in accordance with the Declaration of IUCN Policy on Research Involving Endangered Species.

During the development of the study, meteorological data were collected daily, namely temperature $(T)$ and relative air humidity $(\mathrm{H})$ in the place of cultivation of the experiments, using a thermohygrometer (Fig. 1). 
In both experiments, the treatments were arranged in a $2 \times 2$ factorial scheme, with the application of Si via fertigation (root) and the control (without application of $\mathrm{Si}$ ) combined with two water regimes at $70 \%$ and $40 \%$ of soil water retention capacity, arranged in randomized blocks with six repetitions. The experimental unit consisted of a $7 \mathrm{dm} 3$ vessel filled with $6 \mathrm{dm} 3$ of samples from an Entisol (Quartzipsamment).

Chemical analysis of the soil was carried out for fertility purposes according to the method described by Raij et al. ${ }^{23}$. The following results were found: $\mathrm{pH} \mathrm{CaCl}_{2}=4,3 ; \mathrm{O} . \mathrm{M}$. (organic matter) $=9 \mathrm{~g} \mathrm{dm}^{-3} ; \mathrm{P}$ in resin extractor $=2 ; \mathrm{S}=18 \mathrm{mg} \mathrm{dm}^{-3} ; \mathrm{Ca}=3 ; \mathrm{Mg}=1 ; \mathrm{K}=0,3 ; \mathrm{Al}=0 ; \mathrm{H}+\mathrm{Al}=16 ; \mathrm{SB}$ (sum of bases) $=4 ; \mathrm{CEC}$ (cation exchange capacity) $=20 \mathrm{mmol}_{\mathrm{C}} \mathrm{dm}^{-3} ; \mathrm{V}$ (base saturation $)=21 \%$. The available Si content was determined $\left(3,0 \mathrm{mg} \mathrm{dm}^{-3}\right)$ using the method described by Korndörfer ${ }^{24}$. Soil granulometry was determined using the method described by Gee and $\mathrm{Or}^{25}$, and the following results were found: $540 \mathrm{~g} \mathrm{~kg}^{-}$ 1 of sand, $380 \mathrm{~g} \mathrm{~kg}^{-1}$ of clay and $90 \mathrm{~g} \mathrm{~kg}^{-1}$ of silt.

Thirty days later, lime was applied to the soil to correct acidity, and to increase base saturation $(\mathrm{K}+\mathrm{Ca}+$ $\mathrm{Mg} / \mathrm{K}+\mathrm{Ca}+\mathrm{Mg}+\mathrm{H}+\mathrm{Al}$ ) to $60 \%$. Fertilization was carried out by applying $150 \mathrm{mg} \mathrm{dm}^{-3}$ of $\mathrm{N}, \mathrm{P}$ and $\mathrm{K}$, in the form of ammonium sulfate, triple superphosphate and potassium chloride, respectively, and $5 \mathrm{mg}$ $\mathrm{dm}^{-3}$ of $\mathrm{Zn}$ in the form of zinc sulfate; they were all mixed to the volume of the soil.

The forage was first cut at $12 \mathrm{~cm}$ from the ground level at 45 days after uniform cut of the shoots. At 10 days after this cut, the second growth cycle of the forage started and the treatments were applied, using Si via fertigation and adapting the two study water availability regimes.

The source of Si was sodium silicate and potassium stabilized with sorbitol $\left(113.4 \mathrm{~g} \mathrm{~L}^{-1}\right.$ de Si and $18.9 \mathrm{~g}$ $\mathrm{L}^{-1}$ of $\mathrm{K}_{2} \mathrm{O}$ ), in the concentration of $2.5 \mathrm{mmol} \mathrm{L}^{-1}$, as indicated by Birchall ${ }^{26}$, simulating a $5 \mathrm{~mm}$ irrigation depth every five days. The study of Rocha et al. ${ }^{16}$ on Brachiaria was used as a reference; Si was applied immediately after the first cycle of forage for a period of 40 days.

The levels of soil water availability were determined using the microporosity values found by the tension table method with a $60 \mathrm{~cm}$ high water column; this measurement was performed while considering soil density, which was determined by the ratio of soil dry weight in the greenhouse at $110^{\circ} \mathrm{C}$, for 24 hours, and the volume of undisturbed soil sample ${ }^{27}$. Total microporosity was considered as equivalent to $100 \%$ of soil water retention capacity; however, the water condition was considered as $70 \%$ of this value, as it corresponds to the usual demand for most crops. The water deficit condition was achieved by maintaining the water level at $40 \%$ of the soil water retention capacity. Water availability was controlled daily by the method of weighing the vessels after replacement of evapotranspiration water.

Biological evaluations were carried out at 45 days after the application of the treatments. Leaf +1 (first fully developed leaf) was collected from a tiller chosen at random to determine the content of total phenolic compounds, following the method described by Singleton and Rossi ${ }^{28}$. 
To ensure the adaptation of the leaves to light, quantum yield of PSII was measured between 7 and 9 a.m., on the first fully developed leaf of each plant. Also, maximum variable fluorescence (Fv/Fm), which would be the maximum quantum efficiency of PSII, was determined using a portable fluorometer (Optisciences - Os30P) ${ }^{29}$.

Total chlorophyll index was determined using an indirect electronic chlorophyll meter (Clorofilog Falker ${ }^{\circledR}$ brand). Reading was performed in the middle third of the leaf blade of the first fully developed leaf, which uses 3 light frequency ranges; thus, the optical measurement analyzes the absorption of light by the leaf by estimating the presence of chlorophyll.

Damage to cell membrane integrity was assessed using the method of determining the electrolyte leakage index (EL), proposed by Dionisio-Sese and Tobita (1998) ${ }^{30}$. Ten leaf discs $\left(129 \mathrm{~mm}^{2}\right)$ were collected from the first fully developed leaf and emerged in a beaker containing $20 \mathrm{ml}$ of deionized water, at room temperature for 2 hours. After this period, a reading of the electrical conductivity of the solution (EC1) was performed with the aid of a bench conductivity meter (TDS-3 digital meter). Then, the samples were subjected to heating in an autoclave at $121^{\circ} \mathrm{C}$ for 20 minutes and, after cooling, a new final electrical conductivity reading (EC2) was performed. The electrolyte leakage index was determined considering the following formula: EC1/EC2 x 100. Relative water content in the leaf (RWC) was determined by collecting three leaf discs (with approximately $129 \mathrm{~mm}^{2}$ ) of the first fully developed leaf, which were immediately weighed to measure tissue fresh matter $(\mathrm{Fm})$. After that, the samples were rehydrated in deionized water for 6 hours, to determine turgid matter (Tm), using paper towels to extract the excess water. Dry matter (Dm) was calculated after the discs had remained in a forced air circulation oven at $80^{\circ} \mathrm{C}$ for 24 hours. The relative water content values were determined by the equation proposed by Barrs and Weatherley ${ }^{31}$ : [(Fm - Dm)/(Tm - Dm) $]$ x 100.

Plant height was measured considering the length from the base to the apex of the last leaf, and the number of tillers was counted.

The plants were washed in running water, detergent solution $(0.1 \% \mathrm{v}: \mathrm{v}), \mathrm{HCl}$ solution $(0.3 \% \mathrm{v}: \mathrm{v})$ and deionized water. The plant material was dried in a forced air circulation oven $\left(65 \pm 5^{\circ} \mathrm{C}\right)$ to constant mass and plant dry mass weight was determined.

The Si content in the shoot was measured by extracting the element according to the methodology described by Kraska and Breitenbeck ${ }^{32}$, and Si reading was performed by a spectrophotometer at $410 \mathrm{~nm}$, as indicated by Korndörfer ${ }^{24}$. Si accumulation the shoots of the plants was calculated on the basis of $\mathrm{Si}$ content and dry matter.

Total concentration of $\mathrm{C}$ in the shoots was determined by dry combustion $\left(1000^{\circ} \mathrm{C}\right)$, using an elemental analyzer (LECO Truspec CHNS) calibrated to the standard LECO 502-278 of wheat ( $C=45,00 \%$ e N = $2,68 \%)$. Total $\mathrm{N}$ content was determined following the method of Bataglia et al ${ }^{33}$.

Carbon efficiency was calculated using the equation: (dry matter) ${ }^{2} / \mathrm{C}$ accumulation in the plant ${ }^{34}$. 
The collected data underwent analysis of variance by the F-test, and the averages were compared by Tukey's test, both at 1 and $5 \%$ probability, using the SAS ${ }^{\circledR}$ statistical software ${ }^{35}$.

\section{Results}

Pastures cultivated under water restriction with and without silicon decreased the cumulative amount of the beneficial element. However, pastures cultivated with or without water restriction that had received silicon had an increase in the cumulative amount of silicon (Fig. 2a, d).

Carbon content decreased in pastures that had received silicon regardless of water availability (Fig. 2b, e).

Water restriction increased $\mathrm{N}$ content in both treatments with and without Si for the two forages. Fertigation with silicon only in plants with water restriction increased $\mathrm{N}$ content for the cultivar Massai but decreased it in the cultivar BRS Zuri (Fig. 2c, f).

Water deficit in the two pastures with and without silicon supply decreased the $\mathrm{C}: \mathrm{N}$ ratio except in the Massai cultivar, in which the omission of silicon increased this ratio. In an adequate condition of water availability, there was no difference between the absence and presence of $\mathrm{Si}$ in the pastures (Fig. 3a, d).

Water deficit in pastures did not change the C:Si ratio, regardless of Si. In pastures with or without water deficit, silicon fertigation decreased the C:Si ratio (Fig. 3b, e).

Carbon use efficiency (CUE) decreased in pastures with water restriction without application of silicon, bit it increased in pastures where this element had been applied. In pastures under adequate water availability, fertigation with silicon also increased CUE (Fig. 3c, f).

Pastures under water deficit without fertigation with silicon decreased the relative water content in the plants, while fertigation with silicon increased the relative water content of forages under water deficit (Fig. 4a, d).

Water restriction without silicon supply increased the electrolyte leakage rate in the pastures. The application of silicon only to plants under water deficiency decreased electrolyte leakage in the forage plants (Fig. 4b, e).

Water deficiency affected the production of phenolic compounds depending on the cultivar. In Massai, this variable was only increased with Si supply, but in BRS Zuri, it decreased regardless of Si. Plants with silicon fertigation increased the phenolic compound content in pastures for both water availability conditions (Fig. 4c, f).

In both pastures, the condition of water restriction without silicon supply decreased the quantum efficiency of PSII (Fv/Fm). However, the supply of silicon in pastures, regardless of water condition, increased the photochemical efficiency of PSII (Fig. 5a, C). 
Water deficit, regardless of $\mathrm{Si}$, did not affect the total chlorophyll index in the two pastures. The application of silicon in both water regimes increased the total chlorophyll index in the pastures (Fig. 5b, d).

Water restriction with or without silicon supply decreased the height of the two pastures, and the application of silicon in the two water regimes increased their height (Fig. 6a, d).

Water restriction with or without silicon supply decreased the number of tillers from the two pastures, except for the BRS Zuri cultivar that had received Si. The application of silicon increased the number of tillers from the two pastures in the two water regimes, except for cultivar Massai without water restriction (Fig. 6b, e).

Dry weight of the two pastures decreased under water deficit regardless of silicon. However, there was an increase in dry matter for the pastures after Si had been applied, with or without water restriction (Fig. 6c, f).

\section{Discussion}

Drought frequently occurs in pastures in different cultivation regions in the world and causes severe biological damage, decreasing forage supply ${ }^{7}$ and, consequently, impairing animal production on pasture. The use of Si can help offer an efficient and sustainable model for livestock.

In our study, we showed evidence that water deficit in the Panicum maximum pasture, regardless of cultivar, especially the addition of Si to the crop, causes important damage to plant growth by changing homeostasis, i.e., decreasing the $\mathrm{C}: \mathrm{N}$ ratio by reducing the concentration of $\mathrm{C}$ in the plant, thus inducing instability in the metabolism of the crop, especially in terms of physiological processes. Thus, it was clear that water deficit aggravated the physiological stress in the pastures owing to an increase in electrolyte leakage, followed by a decrease in $\mathrm{Fv} / \mathrm{Fm}$, that is, there was a decrease in the photosynthetic efficiency associated with the lower relative water content in the plant; consequently, the growth of the two cultivars of Panicum maximum was decreased.

Although this species has a high capacity for dry matter accumulation because it has a high protein content ${ }^{36}$, it is sensitive to drought ${ }^{37}$. Such damage to plant growth that is caused by drought, is due to the loss of stoichiometric stability of nutrients ${ }^{38}$, which concentrates the mass balance of various elements between plants and their environments ${ }^{39}$.

To mitigate the damage caused by water deficit in the pasture, there is a promising alternative, namely the use of $\mathrm{Si}$, which plays a vital role in the physiological, metabolic and/or functional processes of plants ${ }^{40}$ if the element is adequately absorbed by the crop. In our study, we found evidence of the high capacity of the study pastures to absorb of $\mathrm{Si}$ when under water restriction. This was due to the fact that Panicum maximum is a Si-accumulating species (Si leaf content $>10 \mathrm{~g} \mathrm{~kg}^{-1}$ ), because the plants must have specific efficient carriers in the process of Si absorption (monosilicic acid) ${ }^{20,41}$. 
The high Si absorption by the pastures was important because it was enough to promote changes in the concentration of $\mathrm{C}$ and $\mathrm{N}$ of the pastures under water deficit and, consequently, in the $\mathrm{C}: \mathrm{N}$ ratio. However, it varied depending on the cultivar, as it was decreased in the Massai cultivar but increased in the BRS Zuri cultivar, owing to the fact that there was an increase in the $\mathrm{N}$ content in the former cultivar while the opposite occurred in the latter one. This may have occurred because the cultivar Massai appears to have higher $\mathrm{N}$ absorption efficiency when compared to BRS Zuri. One cultivar or species may have greater absorption efficiency than another because it has a more efficient nitrogen transporter, that is, it has better kinetic indexes, such as low KM and minimum concentration, and this is governed by a genetic factor ${ }^{42}$.

In addition, the effect of decreasing the C:Si ratio in plants cultivated under water restriction is a result of Si supply, which promoted high element absorption and decreased $\mathrm{C}$ concentration in the two pastures. Anyway, there was evidence of the importance of $\mathrm{Si}$ in elementary stoichiometry in plants under water stress, a fact that was also reported by Long et al. ${ }^{18}$ in study with banana trees under water deficit.

The benefit of stoichiometric homeostasis was reflected in the high metabolic efficiency of $\mathrm{C}$, that is, $\mathrm{Si}$ had a profound impact on the increased $\mathrm{C}$ use efficiency, induced in the two pastures of Panicum maximum under water restriction (Fig. 3b, e). This fact was also reported in pastures of Brachiaria spp. drought ${ }^{16}$ and in sugarcane plants, but there was no water stress ${ }^{43}$. This increase in the efficiency of $C$ use (Fig. 3c, f) by Si may have occurred in both pastures because there was a clear decrease in the $C$ content in plants grown under water restriction (Fig. 2b, e).

Hao et al. ${ }^{19}$ reported that they had also found similar results in native grass species, in which high $\mathrm{Si}$ content is associated with low levels of $\mathrm{C}$. This decrease in the concentration of $\mathrm{C}$ may have occurred because the plant, when absorbing the beneficial element, applies an "exchange strategy" to $C$, particularly in components of the cell wall such as cellulose, since the energy cost of including $\mathrm{Si}$ in the carbon chain is lower than that of including $\mathrm{C}$ itself ${ }^{44}$. This way, there is an improvement in the homeostasis of resistance to water deficiency in pastures. There are reports indicating that the increase in Si in plant tissues may decrease the synthesis of lignin in the cell wall, which has a high energy cost synthesis ${ }^{45}$; the plant uses a "low cost strategy" when occupying binding sites between the components of the cell wall, providing similar structural resistance to that of lignin ${ }^{46}$.

These findings may support the promising role of $\mathrm{Si}$ in pasture management. This was clear in view of the effect of Si on elemental stoichiometry homeostasis in the two forages grown under water restriction, which favored vital physiological processes by increasing the relative water content of the plant by approximately $14 \%$ (Fig. 4a, d). This finding was confirmed by other authors in crops under water restriction that had received Si; for example, the studies of Rocha et al. ${ }^{16}$ on pasture and de Oliveira Filho et al. ${ }^{17}$ and of Teixeira et al. ${ }^{47}$ in sugarcane plants.

This physiological improvement promoted by Si to attenuate water deficit in pastures was also probably due to the reduction of oxidative stress, as there was a decrease in cell electrolyte leakage (Fig. 4b, e), 
driven by the increase of the non-enzymatic antioxidant compound in the two forages (Fig. 4c, f) or by the activity of antioxidant enzymes ${ }^{48}$. This fact decreases reactive oxygen species, which are common in plants under water deficit ${ }^{49}$. Another effect of $\mathrm{Si}$ that demonstrates the attenuation of oxidative stress in pastures under water deficit was evidenced by the increase in Fv/Fm (Fig. 5a, c); in other words, it favored photosynthetic efficiency.

In addition, silicon, by protecting photosynthetic pigments, is also indicative of decreased oxidative stress 40 , a fact found in our study, as the beneficial element increased the total chlorophyll index in the two forages under water deficit (Fig. 5b, d). Wang et al. ${ }^{50}$ reported that the effect of $\mathrm{Si}$ is to delay the degradation of the chlorophyll-protein complexes, as the element alters the protein components of the thylakoid, thus optimizing the light collection and stability of the PSI.

The mitigating effects of $\mathrm{Si}$ on the physiological processes of the two pastures grown under water deficit were responsible for increasing the growth of the forage by promoting an increase of $12 \%$ in plant height (Fig. 6a, d), 31\% in the number of tillers (Fig. 6b, e), which is one of the main components of pasture production. This resulted in a $25 \%$ increase in dry matter accumulation compared to the pasture without $\mathrm{Si}$ (Fig. 6c, f). The mitigating effect of Si on water deficit with a view to increasing plant growth had already been reported in forage crops such as pencilflower ${ }^{51}$ and other crops like wheat ${ }^{52}$ and rice ${ }^{53}$. In those cases, this effect is often attributed only to the improvement of some physiological or biochemical aspects of the plant.

In view of the results discussed above, the hypothesis of this research can be accepted, since the effect of $\mathrm{Si}$ in the attenuation of water deficit is due to the improvement of stoichiometric homeostasis of the $\mathrm{C}: \mathrm{N}$ and $\mathrm{C}: \mathrm{Si}$ ratios and, consequently, in the conversion capacity of cumulative $\mathrm{C}$ in the plant into dry matter weight, considering some physiological processes that take place and the growth of Panicum maximum (Fig. 7).

Our study showed that the effect of $\mathrm{Si}$ on the attenuation of drought is not restricted only to physiological aspects involving increased water content of the plant and photosynthetic or biochemical efficiency. It also begins to exert regulation on elemental stoichiometric homeostasis, which was for the first time in Panicum maximum, proving this new biological strategy of plants that had also found by Rocha et al. ${ }^{16}$ in Brachiaria spp. and by Hao et al. ${ }^{19}$ in other forage grasses.

Animal production depends on the amount of biomass produced for grazing, and the report of Habermann et al. ${ }^{54}$ has indicated that climate changes, such as droughts, are threatening pasture production and have a negative impact on animal and protein production. To solve this, the present research is a reference for the management of fertirrigation with Si during the growth of $P$. maximum, which is a sustainable alternative to improve production with greater nutritional balance even under water restriction in the soil, favoring water use efficiency in cultivation. Włodarczyk et al. ${ }^{55}$ stated that the beneficial element in the soil does not produce greenhouse gases, and there are no negative impacts on the production environment. 
The future perspectives would be to conduct further studies focusing on the benefits of Si in elementary stoichiometry and its relationship with physiological and biochemical aspects, but using other forage species, especially dicotyledons sensitive to water deficit, which have different mechanisms for Si absorption. This will allow a better understanding of whether the Si mechanisms that attenuate drought in monocotyledons also occur in dicotyledons.

\section{Conclusion}

Panicum maximum cultivars Massai and BRS Zuri are sensitive to water deficit without silicon supply, which causes disturbance in stoichiometric homeostasis and consequently in physiological aspects of the crop.

Water deficit was attenuated by $\mathrm{Si}$, which had been applied via fertigation to favor the growth of the two cultivars of Panicum maximum. It stabilized the stoichiometric homeostasis of C:N and C:Si, which is responsible for increasing the conversion capacity of cumulative $\mathrm{C}$ in the plant into dry matter, thus contributing to some physiological processes in the plant - for example, increasing both the water content of plant tissues and photosynthetic efficiency.

The present study highlights the importance of plant nutrition associated with the physiological function of Si but neglected its effects on the stoichiometry of $\mathrm{C}$ and $\mathrm{N}$, addressed in most research on pastures usually grown under water restriction.

\section{Declarations}

Acknowledgments: To the support of São Paulo State University (UNESP).

Author contributions: J.R.R.: Conceptualization, Methodology, Software, Formal analysis, Investigation, Data curation, Writing- Original draft preparation, Writing - Review \& Editing, Visualization. R.M.P.: Term, Methodology, Validation, Investigation, supervision, Project administration.: M.C.P.: Resources, Data curation.

Funding Information: This study was financed in part by the Coordenação de Aperfeiçoamento de Pessoal de Nível Superior - Brasil (CAPES) - Finance Code 001.

Conflict of interest: The authors declare that they have no conflict of interest.

\section{References}

1. Chang, J. et al. Climate warming from managed grasslands cancels the cooling effect of carbon sinks in sparsely grazed and natural grasslands. Nat. Commun, 12, 1-10 (2021).

2. Delevatti, L. M. et al. Effect of nitrogen application rate on yield, forage quality, and animal performance in a tropical pasture. Sci. Rep, 9, 1-9 (2019). 
3. Cruz, J., de Martins, O. \& Jeromini, C. C. T. S. \& da Silva, G. Z. Production fields and physiological quality of Panicum maximum jacq. Cv. mombasa seeds. Biosci. J, 36, 2050-2059 (2020).

4. Pezzopane, J. R. M. et al. Panicum maximum cv. Tanzânia: climate trends and regional pasture production in Brazil. Grass Forage Sci. 72, 104-117(2017).

5. Kemesyte, V., Statkeviciute, G. \& Brazauskas, G. Perennial Ryegrass Yield Performance under Abiotic Stress. Crop Sci, 57, 1935-1940 (2017).

6. Ahammed, G. J., Xu, W., Liu, A. \& Chen, S. Endogenous melatonin deficiency aggravates high temperature-induced oxidative stress in Solanum lycopersicum L. Environ. Exp. Bot, 161, 303-311 (2019).

7. Latef, A. A. H. A. et al. Arbuscular mycorrhizal symbiosis and abiotic stress in plants: A review. Journal of Plant Biology, 59, 407-426 (2016).

8. Sinclair, T. R. \& Rufty, T. W. Nitrogen and water resources commonly limit crop yield increases, not necessarily plant genetics. Glob. Food Sec, 1, 94-98 (2012).

9. Oki, T. \& Kanae, S. Global hydrological cycles and world water resources., 313, 1068-1072 (2006).

10. Monteiro, J. G., Cruz, F. J. R., Nardin, M. B. \& dos Santos, D. M. M. Crescimento e conteúdo de prolina em plântulas de guandu submetidas a estresse osmótico e à putrescina exógena. Pesqui. Agropecu. Bras, 49, 18-25 (2014).

11. Borjas-Ventura, R., Alves, L. R., de Oliveira, R., Martínez, C. A. \& Gratão, P. L. Impacts of warming and water deficit on antioxidant responses in Panicum maximum Jacq. Physiol. Plant. 165, ppl.12907(2018).

12. dos Santos, L. C. N., Teixeira, G. C. M., Prado, R. M., Rocha, A. M. S. \& Pinto, R. C. dos S. Response of pre-sprouted sugarcane seedlings to foliar spraying of potassium silicate, sodium and potassium silicate, nanosilica and monosilicic acid. Sugar Tech 22, 773-781(2020).

13. Harvey, J. T. \& Leffler, A. J. Differential stoichiometric homeostasis and growth in two native and two invasive C3 grasses., 193, 857-865 (2020).

14. Abd El-Mageed, T. A., Shaaban, A., Abd El-Mageed, S. A., Semida, W. M. \& Rady, M. O. A. Silicon defensive role in maize (Zea mays L.) against drought stress and metals-contaminated irrigation water. Silicon, 1-12 https://doi.org/10.1007/s12633-020-00690-0 (2020).

15. Jinger, D. et al. Crop productivity, grain quality, water use efficiency, and soil enzyme activity as influenced by silicon and phosphorus application in aerobic rice (Oryza sativa). Commun. Soil Sci. Plant Anal, 51, 2147-2162 (2020).

16. Rocha, J. R., Prado, M., Teixeira, R., Oliveira Filho, A. S. \& G. C. M. \& B. Si fertigation attenuates water stress in forages by modifying carbon stoichiometry, favouring physiological aspects. J. Agron. Crop Sci. jac, 12479, https://doi.org/10.1111/jac.12479 (2021).

17. de Oliveira Filho, A. S. B. et al. Silicon attenuates the effects of water deficit in sugarcane by modifying physiological aspects and C:N:P stoichiometry and its use efficiency. Agric. Water Manag, 255, 107006 (2021). 
18. Long, M. et al. Effects of water and exogenous Si on element concentrations and ecological stoichiometry of plantain (Plantago lanceolata L.). J. Plant Nutr, 41, 1263-1275 (2018).

19. Hao, Q. et al. Silicon affects plant stoichiometry and accumulation of $C, N$, and $P$ in grasslands. Front. Plant Sci, 11, 1304 (2020).

20. Ma, J. F. \& Yamaji, N. A cooperative system of silicon transport in plants. Trends Plant Sci, 20, 435442 (2015).

21. Ashfaque, F., Inam, A., Inam, A., Iqbal, S. \& Sahay, S. Response of silicon on metal accumulation, photosynthetic inhibition and oxidative stress in chromium-induced mustard (Brassica juncea L.). South African J. Bot, 111, 153-160 (2017).

22. Kim, Y. H., Khan, A. L., Waqas, M. \& Lee, I. J. Silicon regulates antioxidant activities of crop plants under abiotic-induced oxidative stress: A review. Front. Plant Sci, 8, 510 (2017).

23. van Raij, B., Andrade, J. C., Cantarella, H. \& Quaggio, J. A. Análise química para avaliação da fertilidade de solos tropicais. Campinas: Instituto Agronômico(2001).

24. Korndörfer, G. Análise de silício: solo, planta e fertilizante(2004).

25. Gee, G. W. \& Or, D. 2.4 Particle-Size Analysis. in Methods of Soil Analysis, Part 4: Physical Methods (eds. Dane, J. H. \& Topp, C. G.)255-293(John Wiley \& Sons, Ltd, 2018). doi:10.2136/sssabookser5.4.c12.

26. Birchall, J. D. The essentiality of silicon in biology. Chem. Soc. Rev, 24, 351-357 (1995).

27. EMBRAPA. Manual de metodos de análises. Manual de métodos de análise de solo(2017).

28. Singleton, V. L. \& Rossi, J. A. Colorimetry of total phenolics with phosphomolybdic-phosphotungstic acid reagents. Am. J. Enol. Vitic, 16, 144-158 (1965).

29. Lichtenthaler, H. K., Buschmann, C. \& Knapp, M. How to correctly determine the different chlorophyll fluorescence parameters and the chlorophyll fluorescence decrease ratio RFd of leaves with the PAM fluorometer. Photosynthetica, 43, 379-393 (2005).

30. Dionisio-Sese, M. L. \& Tobita, S. Antioxidant responses of rice seedlings to salinity stress. Plant Sci, 135, 1-9 (1998).

31. Barrs, H. \& Weatherley, P. A re-examination of the relative turgidity technique for estimating water deficits in leaves. Aust. J. Biol. Sci, 15, 413 (1962).

32. Kraska, J. E. \& Breitenbeck, G. A. Simple, robust method for quantifying silicon in plant tissue. Commun. Soil Sci. Plant Anal, 41, 2075-2085 (2010).

33. Bataglia, O., Furlani, A., Teixeira, J. \& Agronômico, J. G. Métodos de análise química de plantasBoletim técnico 78. (Instituto Agronômico de Campinas (IAC) 1983).

34. Siddiqi, M. Y. \& Glass, A. D. M. Utilization index: A modified approach to the estimation and comparison of nutrient utilization efficiency in plants. J. Plant Nutr, 4, 289-302 (1981).

35. SAS, S. STAT. User's guide, version 9.2 (SAS Inst, Cary, 2008).

36. de Lima, M. E. et al. Intake, digestibility, and milk yield response in dairy buffaloes fed Panicum maximum cv. Mombasa supplemented with seeds of tropical açai palm. Trop. Anim. Health Prod, 53, 
178 (2021).

37. Tiwari, G., Duraivadivel, P., Sharma, S. \& Hariprasad, P. 1-Aminocyclopropane-1-carboxylic acid deaminase producing beneficial rhizobacteria ameliorate the biomass characters of Panicum maximum Jacq. by mitigating drought and salt stress. Sci. Rep, 8, 1-12 (2018).

38. Zeng, D. H. \& Chen, G. S. Ecological stoichiometry: A science to explore the complexitu of living systems. Chinese J. Plant Ecol, 29, 1007-1019 (2005).

39. Austin, A. T. \& Vitousek, P. M. Introduction to a Virtual Special Issue on ecological stoichiometry and global change. New Phytol, 196, 649-651 (2012).

40. Hasanuzzaman, M., Nahar, K., Anee, T. I., Khan, M. I. R. \& Fujita, M. Silicon-mediated regulation of antioxidant defense and glyoxalase systems confers drought stress tolerance in Brassica napus $L$. South African J. Bot, 115, 50-57 (2018).

41. YAN, G., chao, Nikolic, M., YE, M. \& jun XIAO, Z. xi \& LIANG, Y. chao. Silicon acquisition and accumulation in plant and its significance for agriculture. Journal of Integrative Agriculture vol. 17 2138-2150(2018).

42. de Prado, R. M. Mineral nutrition of tropical plants. (Springer International Publishing, https://doi.org/10.1007/978-3-030-71262-4 (2021).

43. Frazão, J. J., Prado, R., de Souza Júnior, M., Rossatto, D. R. \& J. P. \& Silicon changes C:N:P stoichiometry of sugarcane and its consequences for photosynthesis, biomass partitioning and plant growth. Sci. Rep, 10, 12492 (2020).

44. Li, Z. et al. Silicon enhancement of estimated plant biomass carbon accumulation under abiotic and biotic stresses. A meta-analysis. Agronomy for Sustainable Development, 38, 1-19 (2018).

45. Głazowska, S. et al. The impact of silicon on cell wall composition and enzymatic saccharification of Brachypodium distachyon. Biotechnol. Biofuels, 11, 1-18 (2018).

46. Kim, S. G., Kim, K. W., Park, E. W. \& Choi, D. Silicon-induced cell wall fortification of rice leaves: A possible cellular mechanism of enhanced host resistance to blast. Phytopathology, 92, 1095-1103 (2002).

47. Carliane, G., Teixeira, M., Prado, R. D. M., Rocha, S. \& Ca, M. De. Root- and foliar-applied silicon modifies $\mathrm{C}$ : $\mathrm{N}$ : $\mathrm{P}$ ratio and increases the nutritional efficiency of pre-sprouted sugarcane seedlings under water deficit.1-24(2020) doi:10.1371/journal.pone.0240847.

48. Choudhury, F. K., Rivero, R. M., Blumwald, E. \& Mittler, R. Reactive oxygen species, abiotic stress and stress combination. Plant J, 90, 856-867 (2017).

49. Zhang, W. et al. Silicon alleviates salt and drought stress of Glycyrrhiza uralensis seedling by altering antioxidant metabolism and osmotic adjustment. J. Plant Res, 130, 611-624 (2017).

50. Wang, Y., Zhang, B., Jiang, D. \& Chen, G. Silicon improves photosynthetic performance by optimizing thylakoid membrane protein components in rice under drought stress. Environ. Exp. Bot, 158, 117124 (2019). 
51. Olivera Viciedo, D. et al. Changes in soil water availability and air-temperature impact biomass allocation and C:N:P stoichiometry in different organs of Stylosanthes capitata Vogel. J. Environ. Manage, 278, 111540 (2021).

52. Bukhari, M. A. et al. Silicon mitigates drought stress in wheat (Triticum aestivum L.) through improving photosynthetic pigments, biochemical and yield characters. Silicon, 1-16, https://doi.org/10.1007/s12633-020-00797-4 (2020).

53. Ming, D. F., Pei, Z. F., Naeem, M. S., Gong, H. J. \& Zhou, W. J. Silicon alleviates PEG-induced waterdeficit stress in upland rice seedlings by enhancing osmotic adjustment. J. Agron. Crop Sci, 198, 1426 (2012).

54. Habermann, E. et al. How does leaf physiological acclimation impact forage production and quality of a warmed managed pasture of Stylosanthes capitata under different conditions of soil water availability? Sci. Total Environ, 759, 143505 (2021).

55. Włodarczyk, T. et al. Effect of silicon on barley growth and N2O emission under flooding. Sci. Total Environ, 685, 1-9 (2019).

\section{Figures}

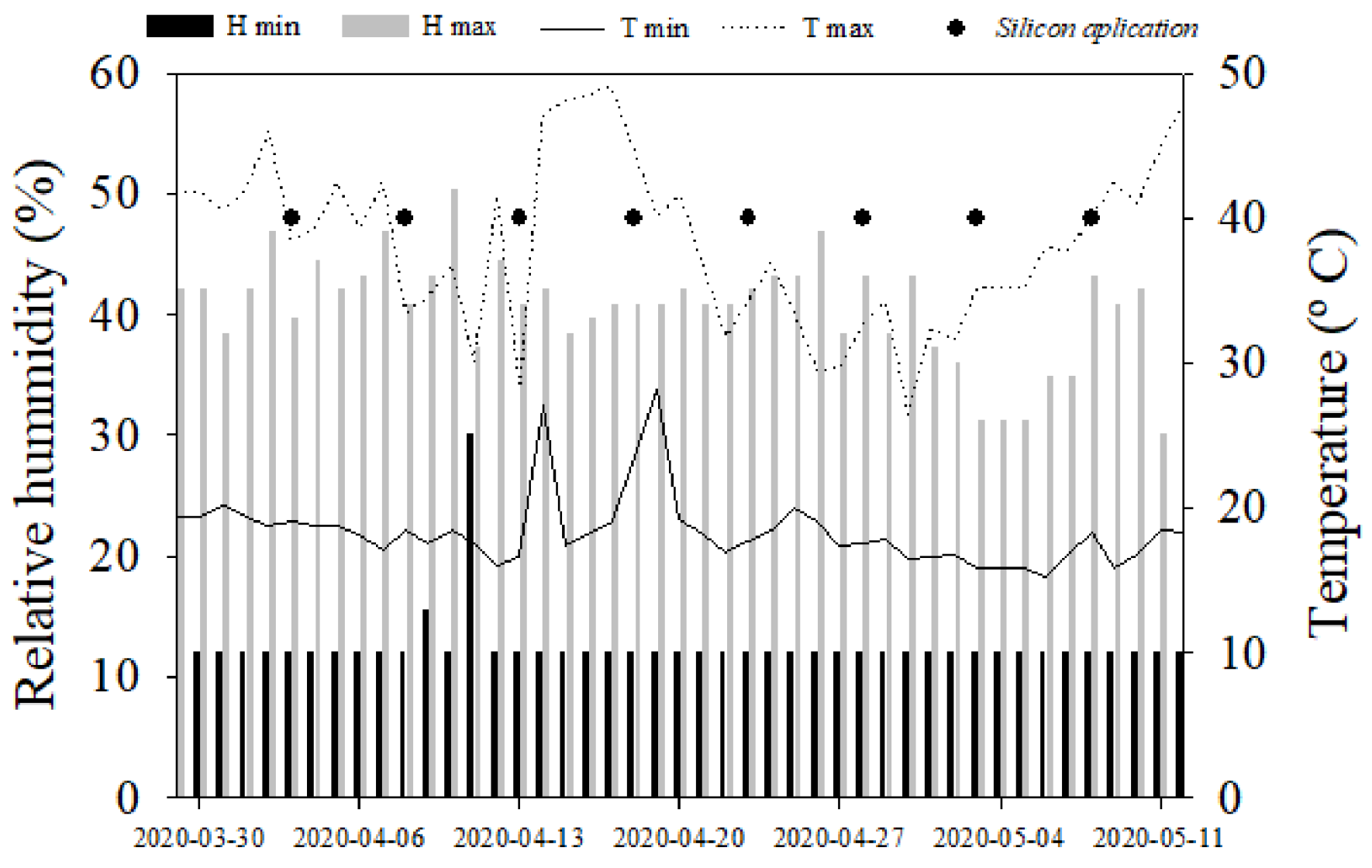


Figure 1

Maximum and minimum air temperature and humidity of the greenhouse and silicon application during the experimental period. $\mathrm{H}$ min: minimum humidity, $\mathrm{H}$ max: maximum humidity, $\mathrm{T}$ min: minimum temperature, $\mathrm{T}$ max: maximum temperature.
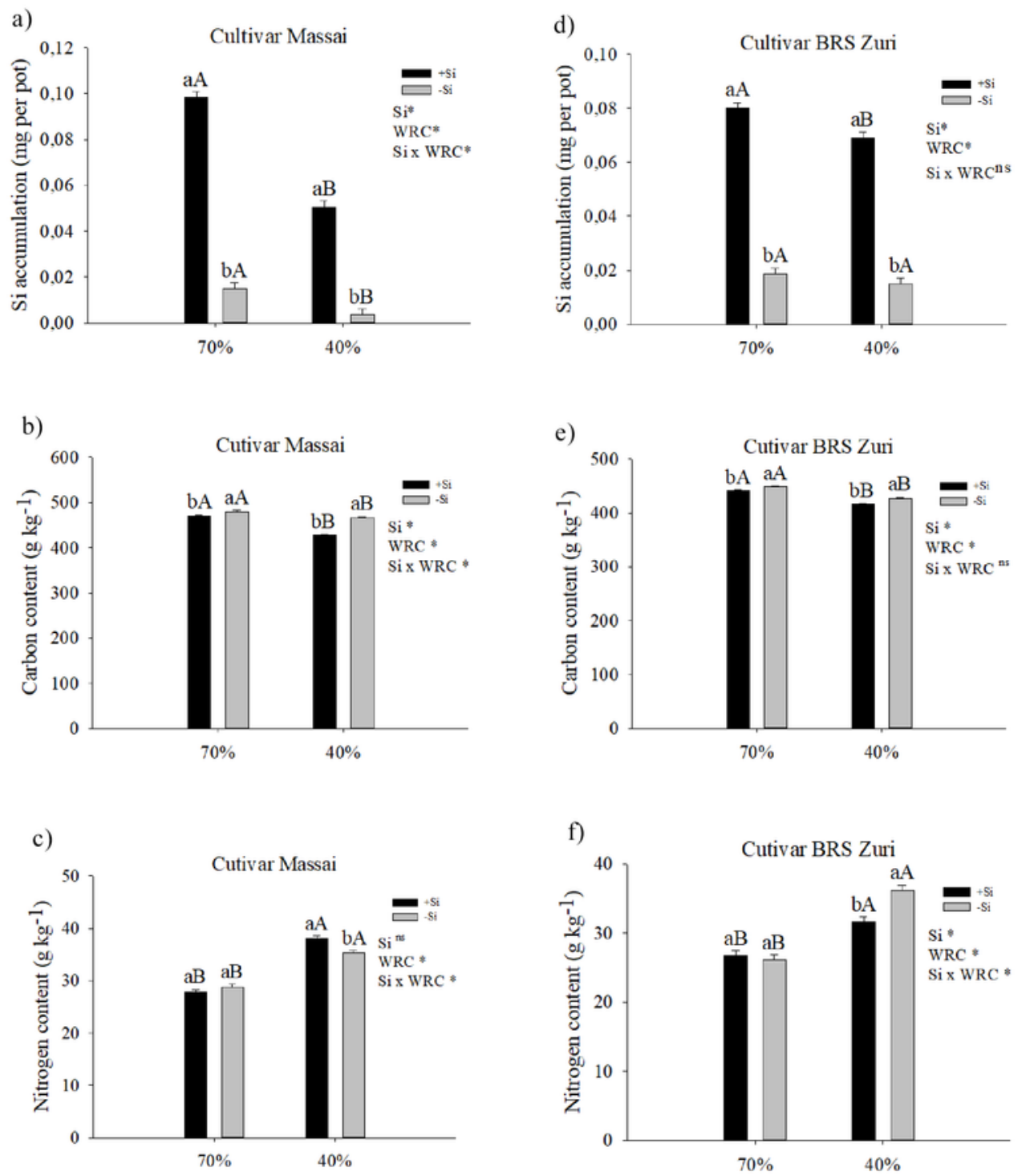

Figure 2 
Silicon (Si) content $(a, d)$, carbon $(C)$ content $(b, e)$ and nitrogen $(N)$ content $(c, f)$ in the aerial part of forage plants cultivated in soil with different soil water retention capacity (WRC) (70 and 40\%) absence ($\mathrm{Si}$ ) and in the presence of fertigation with silicon (+Si). *: significant to $5 \%$ probability by the $\mathrm{F}$ test. Lowercase letters show differences in relation to $\mathrm{Si}$ and uppercase in relation to WRC. The bars represent the standard error of the mean, $\mathrm{n}=6$.
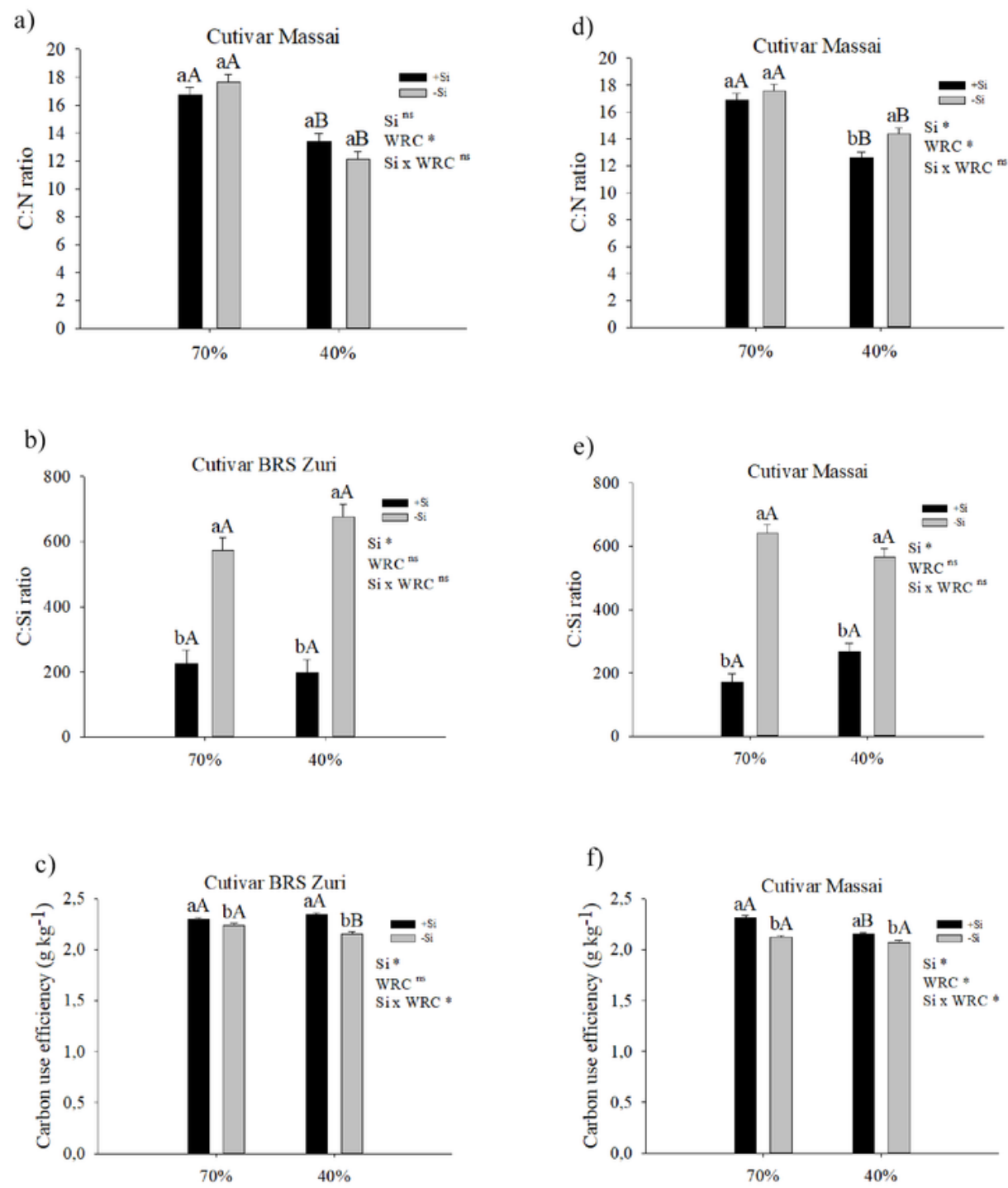

Figure 3 
Ratio C:N (a, d), ratio C:Si (b, e) and carbon use efficiency $(c, f)$ in the aerial part of forage plants cultivated in soil with different soil water retention capacities (WRC) (70 and $40 \%) \%$ ) absence (-Si) and in the presence of fertigation with silicon (+Si). *: significant at $5 \%$ probability. ns: not significant by the test F. Lowercase letters show differences in relation to $\mathrm{Si}$ and capitalization in relation to WRC. The bars represent the standard error of the mean, $n=6$.
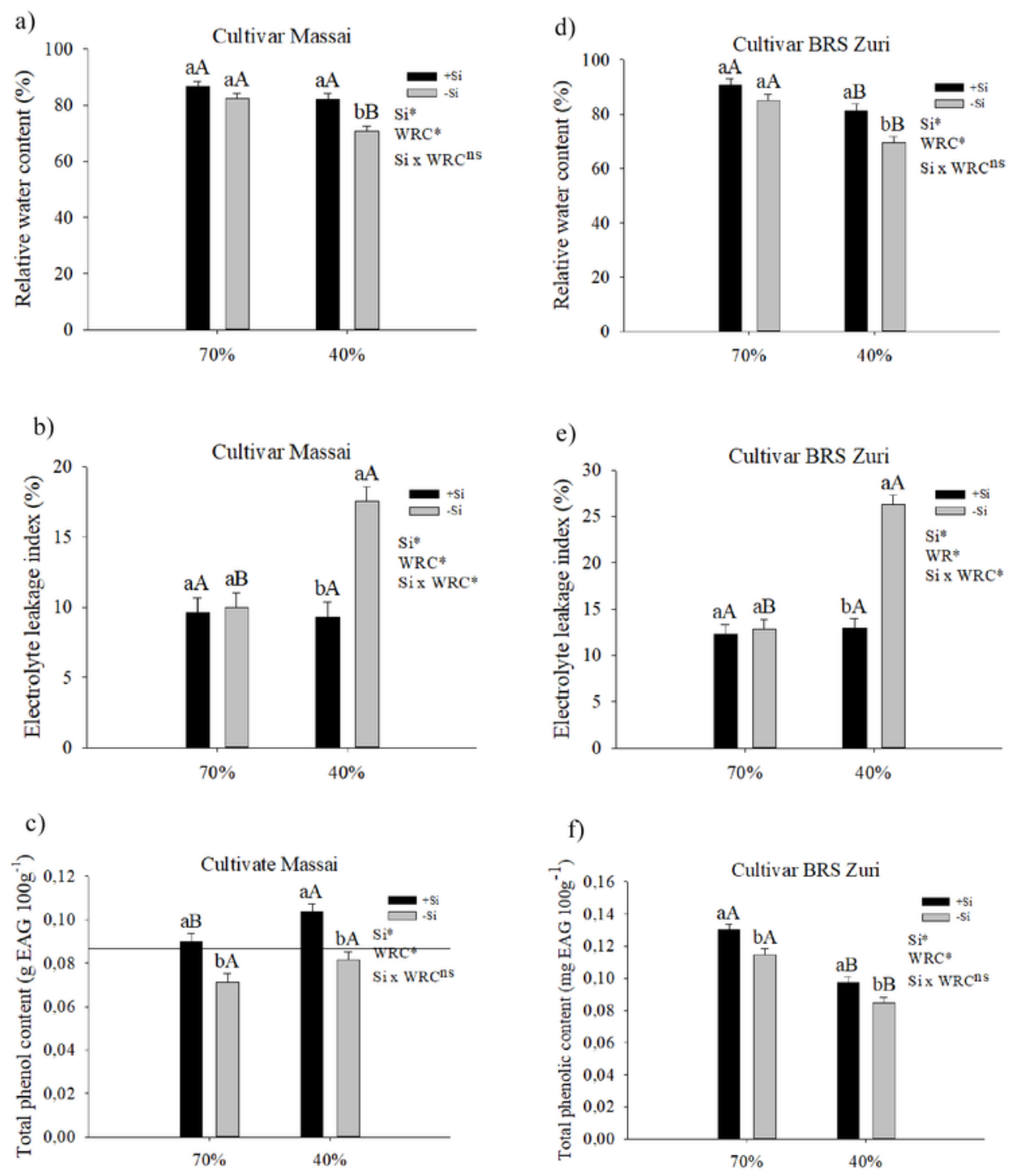

Figure 4 
Relative water content $(a, d)$, electrolyte leakage index $(b, e)$ and Total phenolic content $(c, f)$ of forage plants cultivated in soil with different soil water retention capacities (WRC) (70 and 40\%) absence (-Si) and in the presence of fertigation with silicon (+Si). *: significant at $5 \%$ probability. ns: not significant by the test F. Lowercase letters show differences with respect to $\mathrm{Si}$ and uppercase in relation to WRC. The bars represent the standard error of the mean, $n=6$.

a)

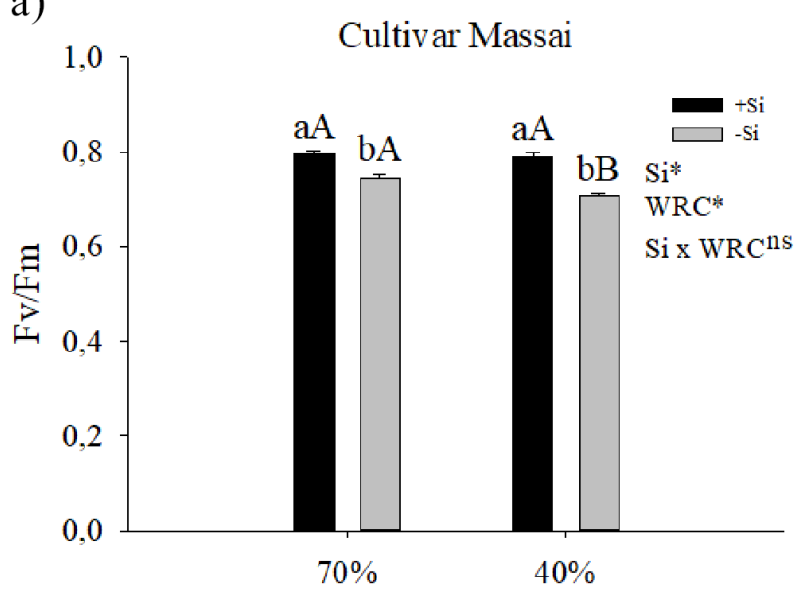

b)

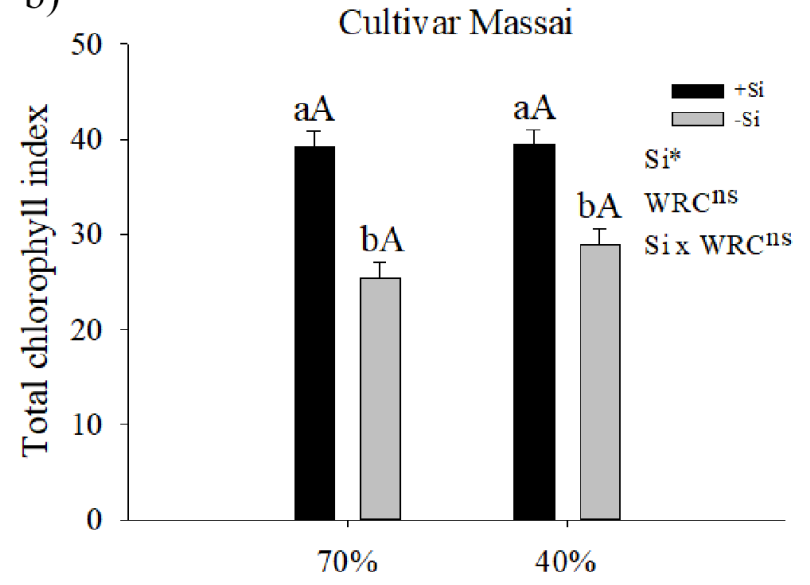

c)

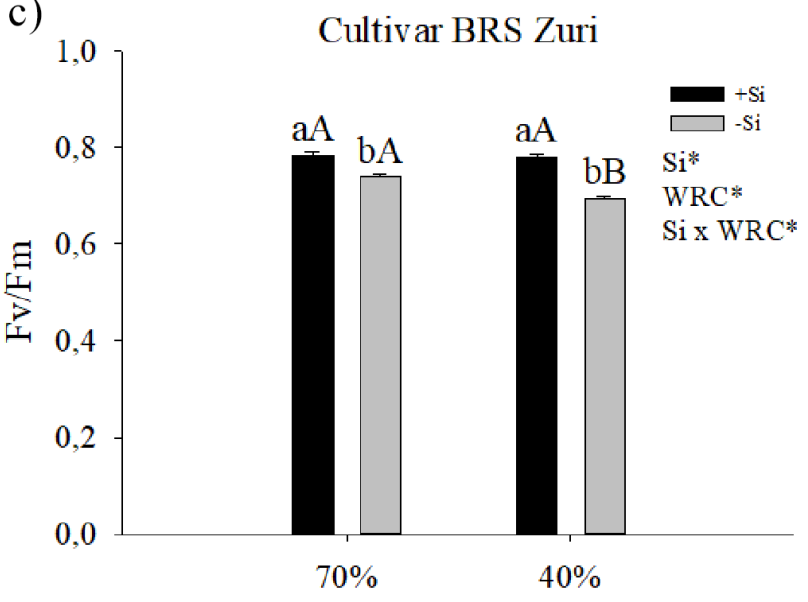

d)

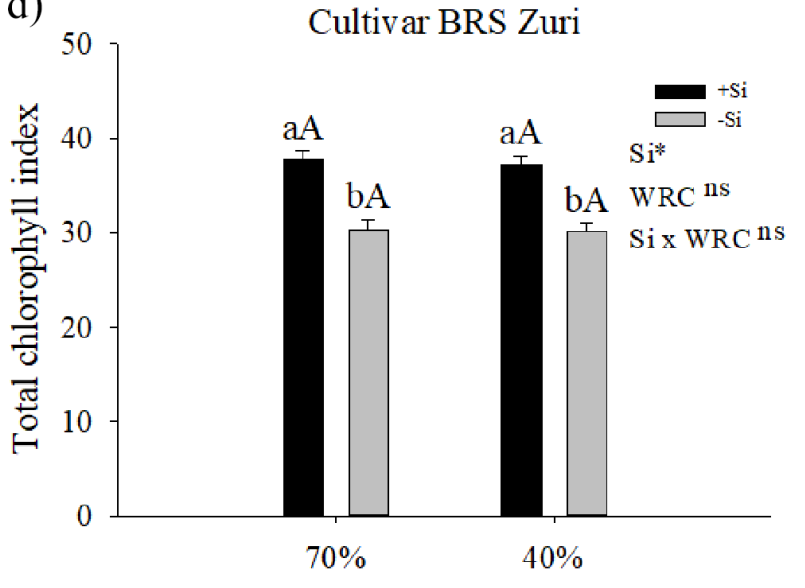

\section{Figure 5}

Quantum efficiency of photosystem II (Fv/Fm) $(a, c)$ and total chlorophyll index (Chl a+b) (b, d) of forage plants grown in soil with different soil water retention capacities (WRC) (70 and 40\%) absence (-Si) and in the presence of fertigation with silicon (+Si). *: significant at $5 \%$ probability. ns: not significant by the test F. Lowercase letters show differences in relation to Si and capitalization in relation to WRC. The bars represent the standard error of the mean, $n=6$. 

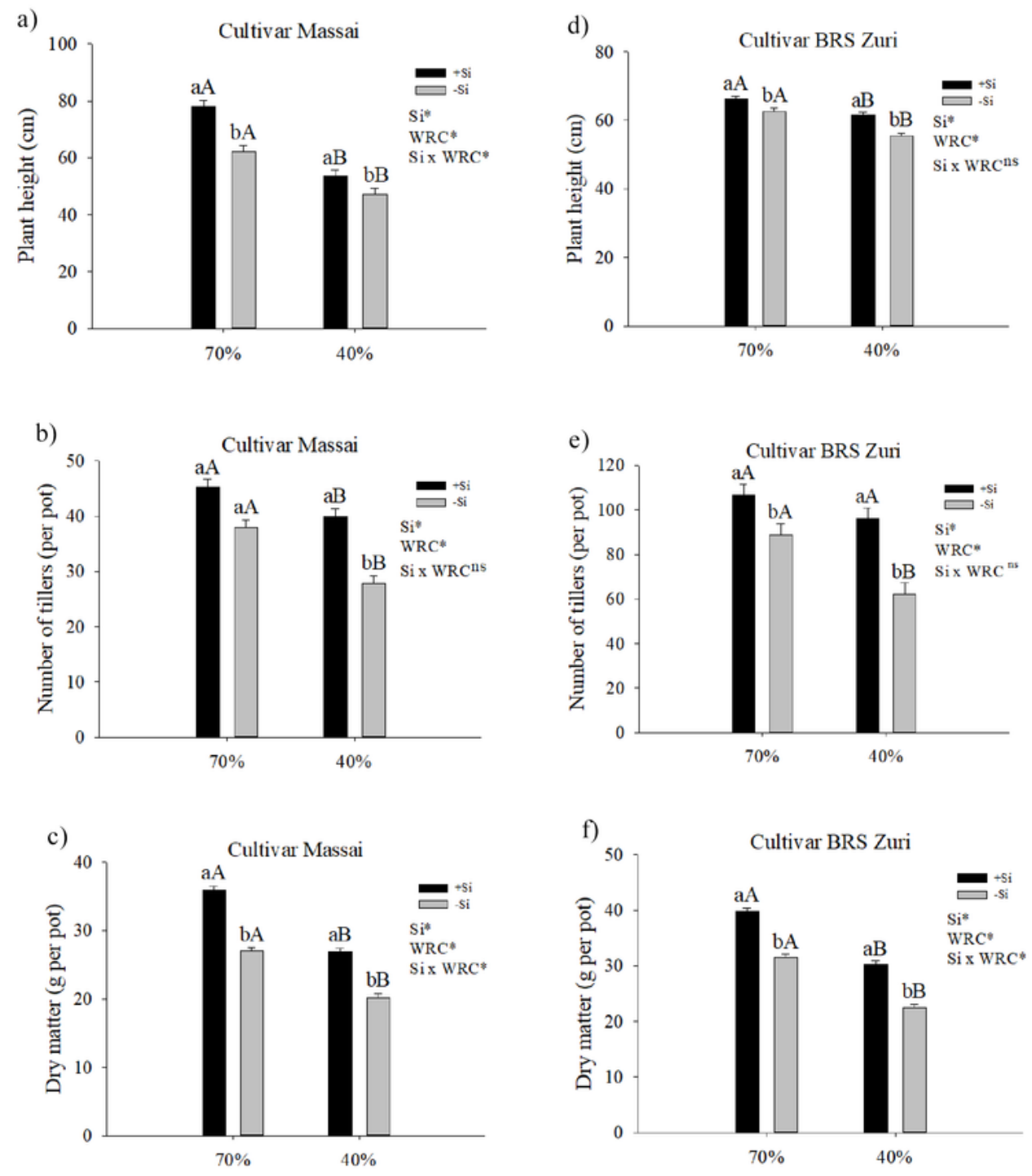

\section{Figure 6}

Plant height $(a, d)$, number of tillers (b, e) and dry matter mass $(c, f)$ of forage plants grown in soil with different soil water retention capacity (WRC) (70 and 40\%) absence (-Si) and in the presence of fertigation with silicon (+Si). ns: not significant by the test F. Lowercase letters show differences in relation to $\mathrm{Si}$ and capitalization in relation to WRC. The bars represent the standard error of the mean, $n=6$. 


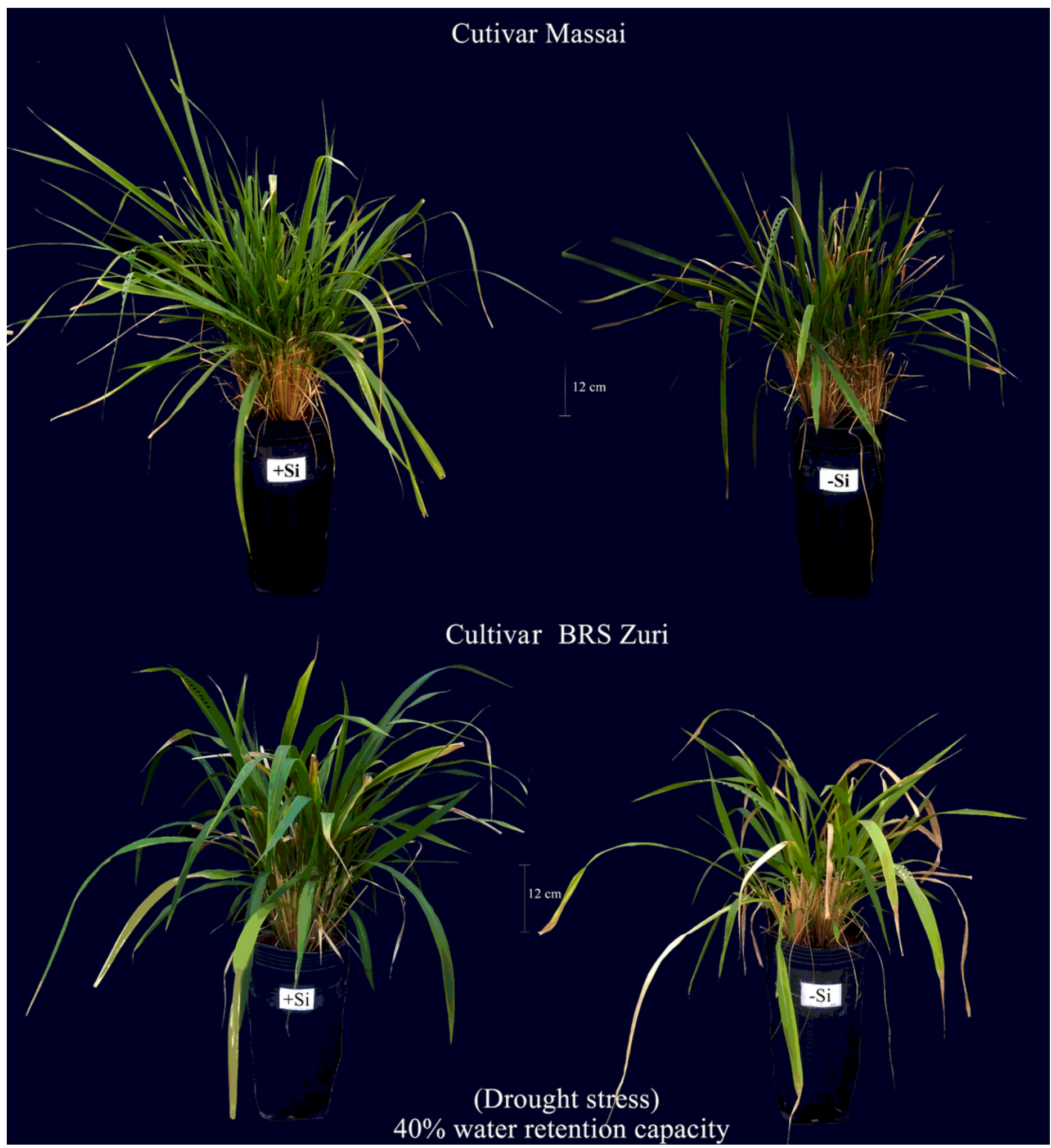

Figure 7

Figure of a forage plant in the condition of water deficit in the absence (-Si) and in the presence of fertigation with silicon $(+\mathrm{Si})$ and a summary of its beneficial in the effects of the plant growth.

\section{Supplementary Files}


This is a list of supplementary files associated with this preprint. Click to download.

- Graphicalabstract.tif 